\title{
Go-Kart - A Working Prototype and Related Simulation Analysis using ANSYS
}

\author{
Dhananjay Paliwal, Abhishek Sharma, Shambhu P Choubisa, Himanshu Pandya
}

\begin{abstract}
A go kart has been designed and developed by mechanical department for the Indian Karting Race (IKR). Indian Karting Race is a national level championship organized and conducted by Imperial Society of Innovative Engineers (ISIE). Various teams from all over the nation try to design and fabricate a low-cost go-kart and then compete with each other in different rounds such as in the designing phase and in safety round. The students had a great chance to prove their knowledge which they gained from the subject of automobile engineering and ic engine. The designing is done in commercial software SolidWorks 2016 and the software ANSYS 14.0 was used to perform finite element analysis. Two designs were made for the comparison so that a suitable design with higher factor of safety, best load consideration and good sporting vehicle can be selected.
\end{abstract}

Keywords: Go-Kart, Indian Karting Race, Imperial Society of Innovative Engineers, Finite Element Analysis

\section{INTRODUCTION}

Go-kart are the vehicles used mainly for the motorsports which is very famous in USA but nowadays many Indian companies and institutes have shown their keen interest in this as a challenging event and also as a source of economy. Indian Karting Race (IKR) is the one such event which encourage students to design and develop the go-kart for the competition and every year this event is organised on Buddh International Circuit (BIC), Greater Noida (India). The event judges the team on the criterion of their design, innovation and on safety features along with the great driving skills. The go-karting is the most economic sport as well as a hobby for some professionals it is a hobby. Go-kart is an open wheeled car with the wheels outside the main body and generally it is a single seat vehicle. With the motorsport comes a great responsibility of sensible design and safety analysis which is mostly done on the commercial software's. SolidWorks [2016] is used to generate the 3-D model of the go-kart and then the simulation [finite element analysis] was done on Ansys 14.0 software. Finite Element Analysis [FEA] is done on the 3-D models to generate the front impact, side impact, total deformation. Based on the result and calculation further changes are discussed.

\section{Designing}

\subsection{Design Requirements}

1. The engine can be used up to the limit of 160-cc.

Revised Manuscript Received on March 5, 2020.

Dhananjay Paliwal*, Techno India NJR, Udaipur (Raj.),313003, INDIA dhananjaypaliwal@gmail.com

Abhishek Sharma, Techno India NJR, Udaipur (Raj.),313003, INDIA Shambhu P Choubisa, Techno India NJR, Udaipur (Raj.),313003, INDIA Himanshu Pandya, Techno India NJR, Udaipur (Raj.),313003, INDIA
2. The engine must be single cylinder, four stroke and air/liquid cooled.

3. The chassis material should be seamless tubes of 1 to 2 inches with a minimum wall thickness of $1.2 \mathrm{~mm}$.

4. The ground clearance of the vehicle must be minimum 1 inch and maximum 5 inches with the driver sitting inside. After the discussion 110-cc engine was provided to the team and on the basis of size and position of the engine two designs were done on the commercial software SolidWorks 2016 and the best design with higher potential was chosen to fabricate.

\subsection{Material Selection}

The AISI 1018 mild steel was chosen because it has the suitable carbon percentage which gives the material both hardness and strength and also it is easy to weld. Also, it was cheaper than the AISI 4130 and was easily available at the time of requirement.

Table 1: Composition of Material

\begin{tabular}{|c|c|}
\hline Chemical Properties & $\%$ \\
\hline Carbon & 0.17 \\
\hline Iron & 98.65 \\
\hline Manganese & 0.75 \\
\hline Phosphorous & 0.030 \\
\hline Sulphur & 0.045 \\
\hline \multicolumn{2}{|c|}{ Table 2: Vehicle Design Parameters } \\
\hline Parameters & Maximum Limit \\
\hline Length & $142.24 \mathrm{~cm}$ \\
\hline Width & $96.52 \mathrm{~cm}$ \\
\hline Weight & $24 \mathrm{~kg}$ \\
\hline
\end{tabular}

\section{Finite Element Analysis}

Ansys workbench is the renowned software used for the static and motion analysis of any structure which is performed before the fabrication to ensure the minimum and maximum limits of the structure under various scenarios.

The finite element analysis is the most certain criterion followed to generate and analyse the front impact, rear impact, side impact and total deformation of any vehicle. Here we analysed two designs and selected the one which was best.

For the analysis the force is always applied on the impacted side of roll cage which is the first point of contact under any collision. For front impact the force is applied on the front side of the roll cage and vice-versa in the case of rear impact. The force is applied on the side for the side impact analysis. 


\subsection{First Design}

It was the first design which we came up with and we analysed this but after the result and discussions we changed the design.

\section{a) Total Deformation}

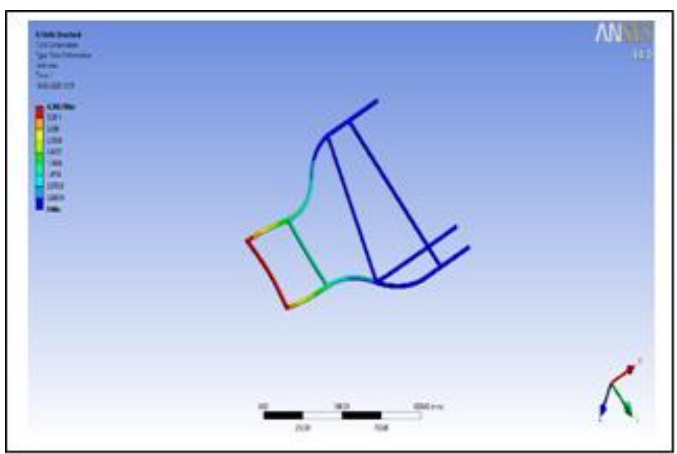

Figure 1: Total Deformation on Front Impact

\section{b) Elastic Strain}

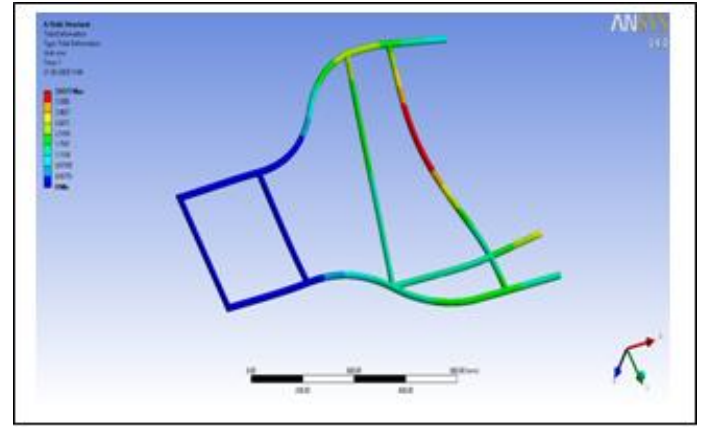

Figure 2: Elastic Strain

c) Rear Impact

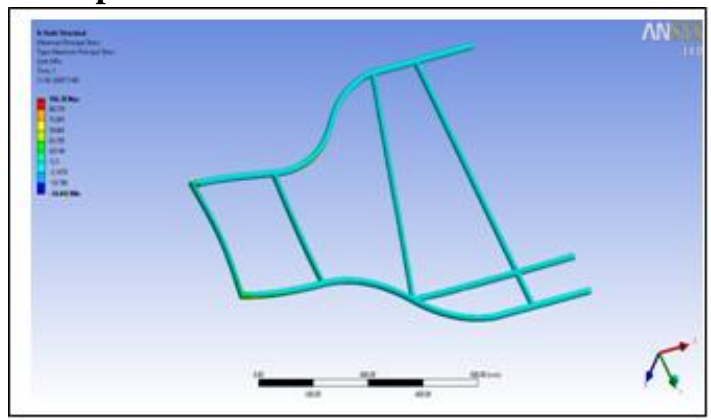

Figure 3: Deformation on Rear Impact

\section{d) Principal Stress}

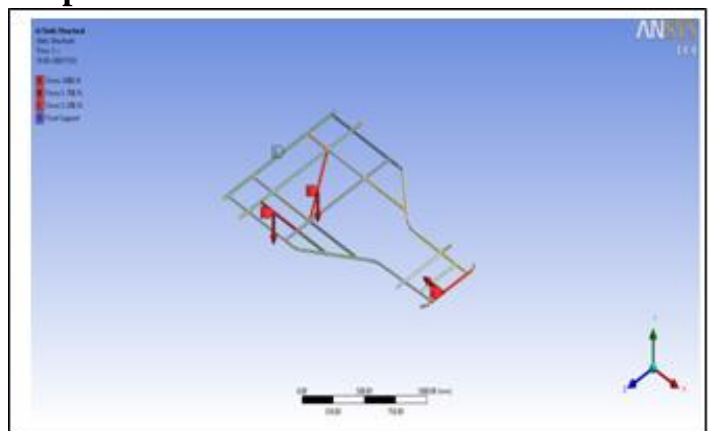

Figure 4: Principal Stress

\subsection{Second Design}

The previous design was not able to withstand the heavy loads and impacts in case of any failure or collision so we improvised the design and introduced some cross sections in design for better strength.

a) Front Impact

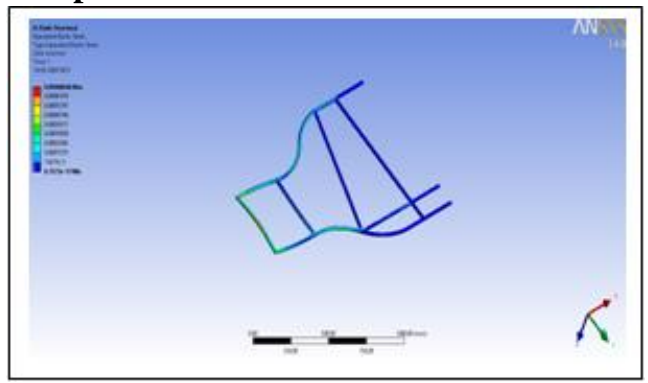

Figure 5: Applied Load for Front Impact

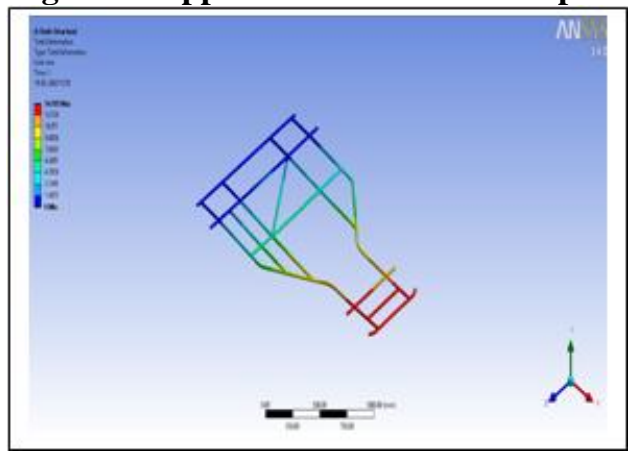

Figure 6: Total Deformation on Front Impact b) Rear Impact

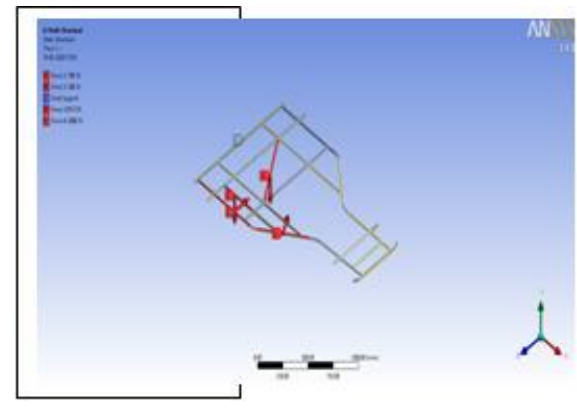

Figure 7: Applied Load for Rear Impact

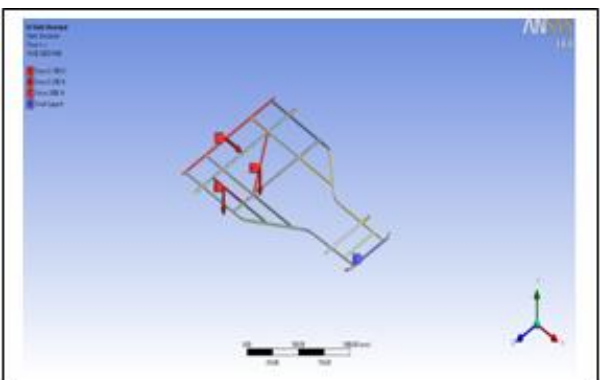

c) Side Impact

Figure 8: Total Deformation on Rear Impact 


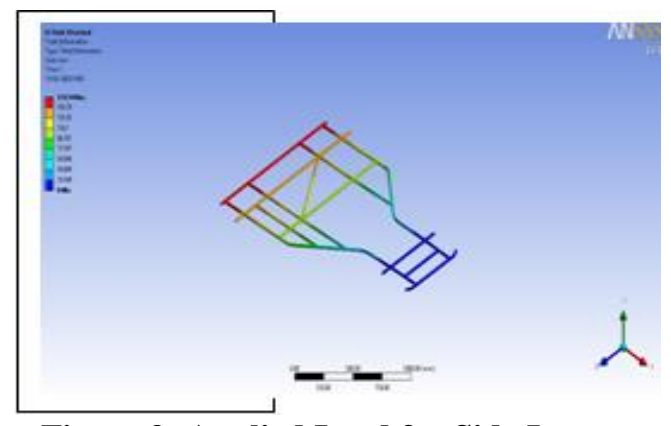

Figure 9: Applied Load for Side Impact

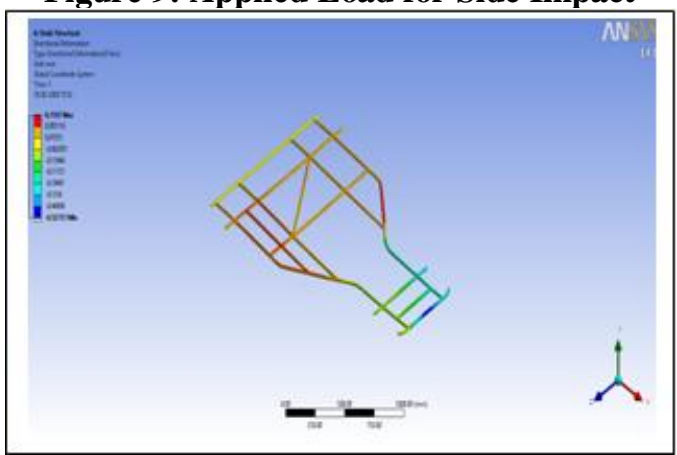

Figure 10: Total Deformation on Side Impact

In both designs the force of $2000 \mathrm{~N}$ was applied and the result was discussed with team and the second design was selected for the fabrication of go-kart.

The results for both the designs were formulated in the tabular form.

\begin{tabular}{|c|c|}
\hline Object Name & ieometry \\
\hline State & Fully Defined \\
\hline \multicolumn{2}{|c|}{ Definition } \\
\hline Type & Design Modeller \\
\hline Length Unit & Meters \\
\hline Element Control & Program Controlled \\
\hline Display Style & Body Colour \\
\hline \multicolumn{2}{|c|}{ Bounding Box } \\
\hline Length $\mathrm{X}$ & $1458.4 \mathrm{~mm}$ \\
\hline Length Y & $935.7 \mathrm{~mm}$ \\
\hline Length Z & $21.3 \mathrm{~mm}$ \\
\hline \multicolumn{2}{|c|}{ Properties } \\
\hline Volume & $8.5495 \mathrm{e}+005 \mathrm{~mm}^{3}$ \\
\hline Mass & $6.7114 \mathrm{~kg}$ \\
\hline Scale Factor Value & 1. \\
\hline \multicolumn{2}{|c|}{$\begin{array}{l}\text { Statistics } \\
\end{array}$} \\
\hline Bodies & 18 \\
\hline Active Bodies & 18 \\
\hline Nodes & 21161 \\
\hline Elements & 4952 \\
\hline Mesh Metric & None \\
\hline \multicolumn{2}{|c|}{ Basic Geometry Options } \\
\hline Solid Bodies & Yes \\
\hline Surface Bodies & Yes \\
\hline Line Bodies & No \\
\hline Parameters & Yes \\
\hline Parameter Key & DS \\
\hline Attributes & No \\
\hline Named Selections & No \\
\hline Material Properties & No \\
\hline \multicolumn{2}{|c|}{ Advanced Geometry Options } \\
\hline Use Associativity & Yes \\
\hline Coordinate System & No \\
\hline
\end{tabular}

\begin{tabular}{|l|c|}
\hline $\begin{array}{l}\text { Reader Mode Saves } \\
\text { Updated File }\end{array}$ & No \\
\hline Use Instances & Yes \\
\hline Smart CAD Update & No \\
\hline $\begin{array}{l}\text { Attach File Via Temp } \\
\text { File }\end{array}$ & Yes \\
\hline Analysis Type & 3-D \\
\hline $\begin{array}{l}\text { Mixed Import } \\
\text { Resolution }\end{array}$ & None \\
\hline $\begin{array}{l}\text { Decompose Disjoint } \\
\text { Faces }\end{array}$ & Yes \\
\hline $\begin{array}{l}\text { Enclosure and } \\
\text { Symmetry Processing }\end{array}$ & Yes \\
\hline
\end{tabular}

Table 3: Results from First Design

\begin{tabular}{|c|c|}
\hline Object & eornetry \\
\hline State & Fully Defined \\
\hline \multicolumn{2}{|c|}{ Definitions } \\
\hline Type & Design Modeller \\
\hline Length Unit & Inches \\
\hline $\begin{array}{l}\text { Element } \\
\text { Control }\end{array}$ & Program Controlled \\
\hline Display Style & Body Colour \\
\hline \multicolumn{2}{|c|}{ Bounding Box } \\
\hline Length $\mathrm{X}$ & $1951.7 \mathrm{~mm}$ \\
\hline Length $Y$ & $21.336 \mathrm{~mm}$ \\
\hline Length Z & 1392. mm \\
\hline \multicolumn{2}{|c|}{ Properties } \\
\hline Volume & $2.1214 \mathrm{e}+006 \mathrm{~mm}^{3}$ \\
\hline Mass & $16.653 \mathrm{~kg}$ \\
\hline $\begin{array}{l}\text { Scale Factor } \\
\text { Value }\end{array}$ & 1. \\
\hline \multicolumn{2}{|c|}{ Statistics } \\
\hline Bodies & 31 \\
\hline Active Bodies & 31 \\
\hline Nodes & 43946 \\
\hline Elements & 17742 \\
\hline \multicolumn{2}{|c|}{ Basic Geometry Options } \\
\hline Parameters & Yes \\
\hline Parameter Key & DS \\
\hline Attributes & No \\
\hline $\begin{array}{l}\text { Named } \\
\text { Selections }\end{array}$ & No \\
\hline $\begin{array}{l}\text { Material } \\
\text { Properties }\end{array}$ & No \\
\hline \multicolumn{2}{|c|}{ Advanced Geometry Options } \\
\hline $\begin{array}{l}\text { Use } \\
\text { Associativity }\end{array}$ & Yes \\
\hline $\begin{array}{l}\text { Coordinate } \\
\text { Systems }\end{array}$ & No \\
\hline $\begin{array}{l}\text { Reader Mode } \\
\text { Saves Updated } \\
\text { Files }\end{array}$ & No \\
\hline Use Instances & Yes \\
\hline $\begin{array}{l}\text { Smart CAD } \\
\text { Update }\end{array}$ & No \\
\hline
\end{tabular}

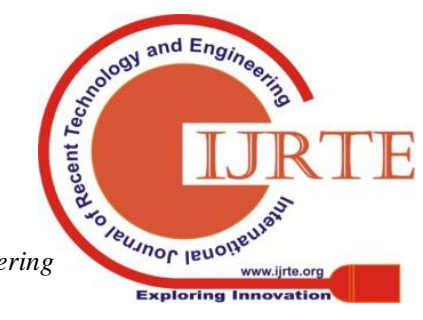




\begin{tabular}{|l|l|}
\hline $\begin{array}{l}\text { Attach File via } \\
\text { Temp File }\end{array}$ & Yes \\
\hline Analysis Type & 3-D \\
\hline $\begin{array}{l}\text { Decompose } \\
\text { Disjoint Faces }\end{array}$ & Yes \\
\hline $\begin{array}{l}\text { Enclosure and } \\
\text { Symmetry } \\
\text { Processing }\end{array}$ & Yes \\
\hline
\end{tabular}

Table 4: Results Obtained from Second Design

\begin{tabular}{|c|c|}
\hline Object Name & Solid \\
\hline State & Meshed \\
\hline \multicolumn{2}{|c|}{ Graphical Properties } \\
\hline Visible & Yes \\
\hline Transparency & 1. \\
\hline \multicolumn{2}{|c|}{ Definition } \\
\hline Supressed & No \\
\hline Stiffness Behaviour & Flexible \\
\hline Coordinate System & Default Coordinate System \\
\hline Reference Temperature & By Environment \\
\hline \multicolumn{2}{|c|}{ Material } \\
\hline Assignment & Structural Steel \\
\hline Nonlinear Effect & Yes \\
\hline Thermal Strain Effects & Yes \\
\hline \multicolumn{2}{|c|}{ Bounding Box } \\
\hline Length $\mathrm{X}$ & $419.48 \mathrm{~mm}$ \\
\hline Length Y & $21.336 \mathrm{~mm}$ \\
\hline Length Z & $622.3 \mathrm{~mm}$ \\
\hline \multicolumn{2}{|c|}{ Properties } \\
\hline Volume & $1.1521 \mathrm{e}+005 \mathrm{~mm}^{3}$ \\
\hline Mass & $0.90444 \mathrm{~kg}$ \\
\hline Centroid $\mathrm{X}$ & $-520.9 \mathrm{~mm}$ \\
\hline Centroid Y & $-4.3158 \mathrm{e}-003 \mathrm{~mm}$ \\
\hline Centroid Z & $-9.5923 \mathrm{e}-003 \mathrm{~mm}$ \\
\hline Moment of Inertia Ip1 & $37825 \mathrm{~kg}-\mathrm{mm}^{2}$ \\
\hline Moment of Inertia Ip2 & $37825 \mathrm{~kg}-\mathrm{mm}^{2}$ \\
\hline Moment of Inertia Ip3 & $78.078 \mathrm{~kg}-\mathrm{mm}^{2}$ \\
\hline \multicolumn{2}{|c|}{ Statistics } \\
\hline Nodes & 1832 \\
\hline Elements & 870 \\
\hline Mesh Metric & None \\
\hline
\end{tabular}

Table 5: Front Part Detailed Information for Second Design

\section{CONCLUSION}

Two designs of go-kart were made and on the basis of factor of safety, load consideration and good sporting vehicle was selected. Along this the environmental impact due to the vehicle was also considered. The use of finite element analysis was very valuable during the designing of go-kart it gave us the upper hand to calculate the load consideration and factor of safety from other commercial software's.

\section{REFERENCES}

1. Rulebook IKR, Imperial Society of Innovative Engineers 2020.

2. Nayak A.O., Ramkumar, G., Manoj, T., Kannan, M.A., Manik, D., \& Chakravarthy, S. (2012). Holistic design and software aided finite element analysis of Off-Road Vehicle. Journal of Mechanical Engineering Research.

3. Parveen Kumar and Harsh Raghuvanshi. (2013) Innovative Design of an All-Terrain Vehicle (ATV). International Journal of Engineering and Advanced Technology (IJEAT).

4. International Journal of Innovative Research in Science, Engineering and Technology (2015)

5. Govardhan Reddy, Md. Hameed, "design report of a go kart vehicle", International Journal of Engineering Applied Sciences and Technology,
2016, Vol. 1, Issue 9, ISSN No. Pages 95- 102, Published Online July August 2016.

\section{AUTHOR PROFILE}

Dhananjay Paliwal, Final Year Student, Mechanical Engineering Department, Techno India NJR Institute of Technology, Udaipur (India).

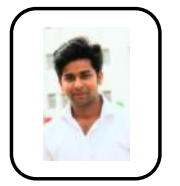

Abhishek Sharma Assistant Professor, Mechanical Engineering Department, Techno India NJR Institute of Technology, Udaipur (India).

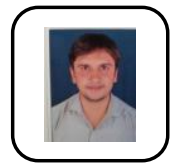

Shambhu P. Choubisa, Assistant Professor, Mechanical Engineering Department, Techno India NJR Institute of Technology, Udaipur (India).

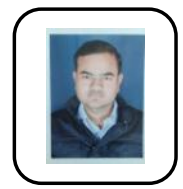

Himanshu Pandya, Assistant Professor, Mechanical Engineering Department, Techno India NJR Institute of Technology, Udaipur (India). 